\section{Commentary: Is it valid to contemplate withholding a proven treatment to patients over age 75 ?}

\author{
Harold G. Roberts, Jr, MD
}

Safely adding concomitant surgical ablation (SA) to patients undergoing cardiac surgery has become increasingly common for patients with a history of atrial fibrillation (AF). ${ }^{1}$ Fueling this trend is the growing evidence that adding SA not only does not increase risk, but it has a salutary impact on short- and long-term survival as well as quality of life. ${ }^{2-4}$ In this issue of the Journal, MacGregor and colleagues ${ }^{5}$ report their experience with SA in which they dichotomized their series to those older and younger than 75 years of age. At 5 years, for those older versus younger than 75 years of age, the probability of remaining alive and free of atrial arrhythmias was $73 \%$ and $51 \%$, respectively. Their main conclusion was that outcomes of the Cox-maze IV (CMP-IV) were worse in elderly patients. They offered the conjecture that the lower success in elderly patients was due to age-related structural and electrophysiologic changes in atrial tissue.

The senior author and his institutional colleagues of this interesting paper $^{5}$ have contributed immensely to our current knowledge of $\mathrm{SA}$ for $\mathrm{AF}$, gaining the respect of the majority of the specialty. However, the interpretation of this particular contribution requires intense scrutiny, lest years of progress in the field potentially tainted by a hypothesis-generating contribution with questionable power and face validity to draw meaningful age-related conclusions. The study $^{5}$ patients were not propensity score matched. Those in the elderly cohort had significantly greater morbidity and mortality. However, this could be readily attributed to their greater risk due to a greater

\footnotetext{
From the Division of Thoracic and Cardiovascular Surgery, West Virginia University, Morgantown, WVa

Disclosures: Author has nothing to disclose with regard to commercial support.

Received for publication March 23, 2020; revisions received March 23, 2020; accepted for publication March 24, 2020; available ahead of print April 9, 2020.

Address for reprints: Harold G. Roberts, Jr, MD, Division of Thoracic and Cardiovascular Surgery, West Virginia University, Morgantown, WV 26506 (E-mail: harold.

roberts@wvumedicine.org).

J Thorac Cardiovasc Surg 2021;162:1529-30

$0022-5223 / \$ 36.00$

Copyright (c) 2020 by The American Association for Thoracic Surgery

https://doi.org/10.1016/j.jtcvs.2020.03.097
}

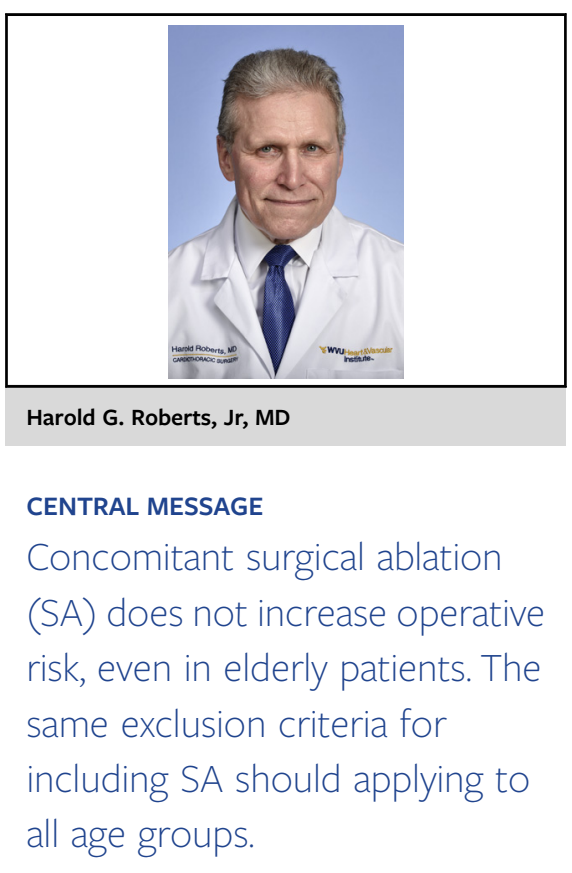

incidence of heart failure and peripheral vascular disease. Inferior elderly outcomes at 5 years were difficult to interpret in that the elderly patients were inherently more likely to die than younger patients. Although the combination of procedures between the 2 groups was similar, the elderly cohort had highly significant increases in clamp and perfusion times, both well known to increase morbidity and mortality. The distribution of paroxysmal and persistent $\mathrm{AF}$ was similar between the 2 groups, yet the elderly cohort inexplicably had more left-sided mazes only, rather than the more effective CMP-IV. As an aside, it was concerning that both cohorts had left-sided mazes and CMP-IVs, yet the Central Message and Perspective Statement implied that all the data were from CMP-IVs. Finally, the elderly patients were more often discharged in AF, a well-known factor in decreasing long-term success.

We take solace that the authors take pains to point out that the increased mortality in the "elderly patients in our study is likely due to the complexity of the patients' clinical condition, not the CMP-IV itself." However, for those of us who routinely apply CMP-IV to our patients with significant $\mathrm{AF}$ burden, it is obvious how much easier it is to manage even critically patients, particularly those with rapid ventricular response, once you 
regain atrioventricular synchrony as well as rate control. A full set of left-sided lesions and control of the left atrial appendage should take no more 20 additional minutes of clamp time. The right-sided lesions can be easily added during the recovery phase of the pump run with the heart warm and beating should that be deemed necessary by the surgeon. An experienced perfusionist with vacuum-assisted venous drainage does not require caval snaring, so the downside to doing a comprehensive set of biatrial lesions is merely the additional right atriotomy.

In summary, this paper provides concern over adding SA when faced with the critically ill, elderly AF patient needing cardiac surgery, but this hypothesis will need much more rigorous validation to have face validity in the presence of far more robust literature. It is absolutely agreed that patients with years of AF with gross left atrial distention and fibrosis are less likely to benefit from SA, and thus the additional benefit of SA should be questioned.
However, the current evidence supports that the majority of patients older than 75 years of age will benefit from relieving their AF burden without increasing the surgical risk while improving the quality and quantity of life.

\section{References}

1. Badhwar V, Rankin JS, Ad N, Grau-Sepulveda M, Damiano R, Gillinov A, et al. Surgical ablation of atrial fibrillation in the United States: trends propensity matched outcomes. Ann Thorac Surg. 2017; 104:493-500.

2. Rankin JS, Grau-Sepulveda M, Ad N, Damiano R, Gillinov A, Brennan J, et al. Associations between surgical ablation and operative mortality after mitral valve procedures. Ann Thorac Surg. 2018;105:1790-6.

3. Badhwar V, Rankin JS, Damiano R, Gillinov A, Bakaeen F, Edgerton J, et al. The Society of Thoracic Surgeons 2017 clinical practice guidelines for the surgical Treatment of atrial fibrillation. Ann Thorac Surg. 2017;103:329.

4. Ad N, Damiano R, Badhwar V, Calkins H, Meir M, Nitta T, et al. Expert consensus guidelines: examining surgical ablation for atrial fibrillation. J Thorac Cardiovasc Surg. 2017; 153:1130.

5. MacGregor R, Khiabani A, Bakir N, Manghelli J, Sinn L, Carter D, et al. Impact of age on atrial fibrillation recurrence following surgical ablation. J Thorac Cardiovasc Surg. 2021;162:1516-28.e1.
See Article page 1516.

\section{Commentary: Should age alter the decision to perform concomitant or stand-alone surgical ablation for atrial fibrillation?}

Niv Ad, MD
From the Division of Cardiac Surgery, University of Maryland School of Medicine, Baltimore; and Thoracic and Cardiac Surgery, Adventist HealthCare White Oak Medical Center, Silver Spring, Md.

Disclosures: Dr Ad is a consultant for Medtronic, a member of the speaker's bureau for AtriCure, a proctor and member of the speaker's bureau for LivaNova, on the advisory board for Nido Surgical, and co-owner for LeftAtrial Appendage Occlusion, LLC.

Received for publication March 30, 2020; revisions received March 30, 2020; accepted for publication March 31, 2020; available ahead of print April 11, 2020.

Address for reprints: Niv Ad, MD, Division of Cardiac Surgery, University of Maryland School of Medicine, 110 S. Paca St, 7th Floor, Baltimore, MD 21201 (E-mail: nivadmd14@gmail.com).

J Thorac Cardiovasc Surg 2021;162:1530-3 $0022-5223 / \$ 36.00$

Copyright $(9) 2020$ Published by Elsevier Inc. on behalf of The American Association for Thoracic Surgery

https://doi.org/10.1016/j.jtcvs.2020.03.135
Check for updates

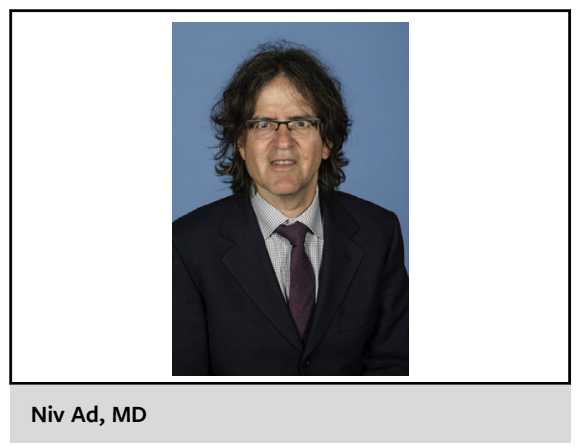

CENTRAL MESSAGE

Age alone should not be used as

the basis to not intervene on

elderly patients. In general,

concomitant surgical ablation is

not associated with increased

risk for major perioperative

complications.

Atrial fibrillation is very common among candidates for open-heart surgery. Despite strong evidence supporting surgical ablation, significant variability exists among 